\title{
IRONY AND MEANS OF ITS REALIZATION IN ENGLISH LITERARY DISCOURSE (TRANSLATION ASPECT)
}

Y. Kats, PhD in Philology, Associate Professor;

Y. Fadieieva, Student

Sumy State University,

2, Rymskogo-Korsakova St., Sumy, 40007, Ukraine

E-mail: juliakatz@ukr.net,yuliana.fadeeva@gmail.com

The notion of "irony" exists in various historical-philosophical and linguistic contexts (from Socrates, Aristotle and to Postmodernism). Each era brought its nuances in its content, but in none of the categories of categories it could not claim a leading role. Therefore, the prospects for its development and study remain open.

In modern linguistics, irony is considered as a style-building feature of the text, which can be implemented at different language levels, from one word, to a holistic text in a mandatory contextual environment. The great significance of the context for decoding irony is due to its intellectualism and, consequently, the growth of its weight in contemporary art, the expansion of the means and mechanisms for its implementation in artistic texts.

In this context, the analysis of linguistic means of irony in the English artistic discourse becomes significant and relevant.

Keywords: irony, stylistic device, expressive means, non-conformity, situational irony, associative irony, negation, lexical level, syntactical level, transformations.

DOI: 10.21272/ Ftrk.2018.10(1)-05

The research reflects on the nature and means of irony realization in English literary texts. In most of linguistic studies irony is considered to be a trope i.e. it refers to a certain word or word combination. There are, however, cases when irony is formed by a word group, a sentence or even a whole text. Thus, irony can be realized on the level of word and word combination (microcontext), text fragment (macrocontext) and a whole text (megacontext), little by little changing from an expressive means into a wide semiotic and esthetic category $[1, \mathrm{p} .68]$.

Irony is complicated for determination and establishing its confines. First of all, it is hidden in lexical semantics and, therefore, is difficult for understanding. Secondly, it is often scattered within a text and can be revealed only in juxtaposition with several units.

The author points out that irony is considered by linguists both in narrow and wide sense. In narrow sense irony is usage of a word that expresses, as s rule, positive evaluation in order to express negative one. Contradicting a situation, real fact or context, a word obtains the meaning that contradicts its usual one. In wide sense, ironic is an utterance which generally seems to express positive or neutral attitude of a speaker, but, in fact, it carries a negative evaluation. Stating non-conformity of subjective ideas about objective state of facts, irony performs synthesis of contraries and, thus, reflects dialectical nature of human thinking [2, pp. 20-23].

The dominant ontological features of irony, concerning its perception by a recipient, are anomality and paradoxicality. These are two differential distinguishing characteristics. Anomality of irony reveals in breach of different norms, they are: language, speech, logical, lingual and ethological, ontological.

Paradoxicality of irony is predetermined, first of all, by deliberate disconformity, contradictory correlation between the form and the content of an ironical utterance, and, secondary, by contextual inappropriateness of irony, because ironic utterance with its form contradicts contextual expectations, is unexpected, illogical in certain context.

(C) Kats Y., Fadieieva Y., 2018 
Anomality and paradoxicality of irony, breaking a complete perception of discourse, appear to be basic signs in its perception by a recipient. They prevent literal understanding of irony, marking the intention of irony producer to express one point of view under the mask of another [3, p. 267].

The thesis also reveals that irony requires some formal signs indicating the opposite content of an utterance. In speech such markers can be represented by, first of all, intonation and various paralinguistic means - mimicry, gesture.

One of the key issues of the research is the classification of irony. Scientists do not have a single approach to the classification of ironical utterances. Many Russian and Ukrainian linguists consider irony as a stylistic device and a category of text. They distinguish evident and hidden, contextual and text-forming, situational and associative irony. Foreign scientists distinguish verbal, situational and dramatical irony. There are also some other types of irony - tragical, philosophic, rhetorical, self-irony, irony of fate, etc.

The research also concentrates on the study of conceptual nature of irony. Negation is characteristic of all language of the world initial, semantically indivisible sense category that cannot be defined through easier semantic elements. It is considered to be one of the means of objection, prohibition, reluctance. One of the possible functions of negation is declining of the thought of communicant, correction or putting some action under taboo [4].

The peculiarity of verbal expression of irony is coexistence of two sense planes, they are: direct explicit and implicit that contradicts direct one. There exist two opposite mental spaces in ironical utterance. The language unit itself (an ironical utterance) comes to a foreground, while the background is based on real cognitive environment [5, p. 51]. In other words, outer and inner structures of an ironical utterance form opposition. Irony, thus, represents conceptual projection of two different mental spaces, opposition of which in a certain context creates ironical evaluation. So, we can state that negation lies in the nature of abovementioned stylistic device and remains its main characteristic feature [5, p. 52].

Studying the conceptual nature of ironical expressions, the author concluded that irony takes exceptional place among stylistic devices since it is based on implicit negation that results from the breach of logical connections within communicative language units. Consequently, in ironical utterances negation concept is expressed on the level of communicative units [3, p. 248].

Basically the thesis reviews problems that can arise in the process of recognizing and understanding irony. The main principle of creating ironical effect is sense non-conformity. The most often it forms on the basis of two meaning of the word - dictionary and contextual. In such cases the language unit has one plane of expression and two planes of content. Moreover, these planes coexist in the consciousness of recipient. In the result of synonymous substitution (that is changing of the form of expression) the ironical meaning remains unchanged, but after substitution of contents the stylistic device of irony becomes lost [6, pp. 43-44].

Certain difficulties in rendering and understanding of irony can arise even on the easiest for its perception lexical level. Particularly difficult are cliché word combinations, while translating of which commenting is improper. Those are cliché word combinations that are the most effective means of irony actualization in English language. The most widespread among them are attributive word combinations [7, p. 25].

The thesis aims at differentiating means of irony realization in English literary texts. The way of irony realization is specific in the usage of nominative lexemes that are proper names - surnames, sobriquets of the characters, names of historical personalities and mythical characters that are allusions [8, p. 208]. Ironical effect here is results from those semantic transformations that are typical for the nominative units with developed semantic structure while using them as "meaningful" names and also as a result of context influence. The basis of ironical meaning is formed by both possibility and impossibility of correlation the name with its bearer.

The means of syntactical level - lexical and syntactical alogisms, parenthetic constructions, syntactical repetitions, different types of sentences - are of importance in 
realization of irony. Parenthetic constructions actualize situational irony on syntactical level. Contrasting juxtaposition of an utterance with a parenthetic sentence changes its semantics, gives a subjective and evaluative modality to the utterance. The usage of parenthetic words has a subsidiary character, because a parenthetic word itself cannot make an ironical effect. The reason is that it reveals its stylistic potential only in complex with other stylistic devices i.e. parenthetic constructions, rhetorical questions, accumulation of homogeneous parts of the sentence. Semantics and stylistic pragmatics of parenthetic words are predetermined by context [9, pp. 3-5].

The author also mentions that specific stylistic devices aimed at creating certain sound effects that is combination of a range of phonetic means are of great importance for making the ironical effect. Phonetic means, however, are of more rare usage in irony than lexical and semantic or stylistic means [1, p.70].

Ironical content can be determined by neologisms, barbarisms, colloquialisms, slang words, idiomatic expressions and also by methods of semantization of lexeme and usage of attributive word combinations. They ensure qualitative actualization of ironical content, performing herewith a range of functions (emotional and evaluative, manipulative, protective, function of relaxation, etc.), activating reader's thinking and ability to analyze.

The thesis also reveals that as a trope and a means of expressing comical in the text, irony can be expressed through other stylistic categories with the help of stylistic devices, such as metaphor, pun, oxymoron, etc. Syntactically irony is not limited with individual tropes, but it can be realized occasionally with the help of parenthetic sentences, parenthetic words, rhetoric questions, accumulation of homogeneous parts of the sentence, gradation of irony and accumulation of language means [10, pp. 15-16].

Citation and repetition are fecund means of actualization of associative irony on the level of the text. In such constructions lexical unit gradually accrues new meanings, changing the semantics. Collation on the level of horizontal and vertical context is of importance for decoding of irony [11, p.101].

The research also concentrates on the possible ways of translation of ironical expressions. While translating irony that was formed by abovementioned means different translator's transformations can be used. They are antonymic, metonymic and other changes caused by necessity of transformation of figurative basis of comic, concretization, concretization and generalization of the meaning in order to overcome lexical and contextual non-conformity, amplification, compensation.

Often irony can be recognized only on the appropriate cultural background. As any utterance with rich cultural background, irony is often hardly possible to transfer into other culture fully. Literal translation of ironical utterance often distorts the primary sense or appears to be absurdity at all, because each culture has its own metaphors, idioms and means of creation of delicate ambiguity [12, pp. 48-51].

The author also emphasizes that it is quite difficult to render the irony, because it also requires the full conveying of the sense while not changing the form. That is why literal and at the same time adequate translation is possible only under conditions of full agreement of social and national cultural associations what happens considerably seldom. Far more often different lexical, grammatical and stylistic translator's transformations are used in translation [13, pp. 200-201]. That means that the question of preserving the content and the form, basing on culturally biased units, remains topical.

The author considers irony to be one of the main elements of direct expressing of the author's attitude in literary texts, means of realization of subjective and evaluative modality and, thus, means of realization of the author's position [12, p. 38].

One of the key issues of research is distinguishing ways of rendering of irony that are used in translation, they are: full translation, expansion of ironical expression, antonymic translation, addition of components [14, p. 166].

Full translation with little lexical or grammatical transformations can be used when it permits not only verbal but also grammatical structure of the ironical expression in the source text, under conditions of full agreement of social and cultural associations. The 
translator will meet no difficulties while translating irony that is expressed in the text with the help of one or two words (adverb, noun, adjective) that are used in an opposite meaning.

The method of expansion of ironical expression can be used in order to preserve lexical and grammatical form of the source text, adding the components that will reveal the meaning of ironical expression more fully.

The next method of translation of irony is antonymic translation - when form of the word or word combination is changed to the opposite one (positive to negative and vice versa).

The author emphasizes that far more difficult are cases when irony is expressed with the help of an idiomatic expression. The problem lies both in rendering the set expression and in preserving the ironical effect. There exists some ways of rendering the idiomatic expressions, they are: with the help of full or near phraseological equivalents, which includes calquing, lexical translation itself and descriptive translation.

In the thesis the author comes to the conclusion that translation of irony directly depends on the way of its expression in the source text. The main purpose in the translation of irony consists in conveying the ironical effect and herewith preserving the means of its expression in the target text. [15, pp. 247-250].

Preference of usage some or other language means of realization in each concrete language depends on historical and cultural conditions of development of the national language community.

According to the classification of S.I. Pochodnia, situational irony results from the contrast between situational context and direct meaning of the word, word combination and the sentence and is realized in micro- and macrocontexts (within a sentence or a paragraph). Analyzing a range of examples, the author states that situational irony can be formed with the help of usage of the great amount of stylistic devices on different levels:

- On the lexical level these are language units that belong to the colloquial style, including vulgar words, barbarisms, metaphors, metonymy, hyperboles;

- On the syntactical level these are different types of repetitions, zeugma, oxymoron, pun, rhetorical questions, parenthetic constructions;

- On the lexical and semantic level these are epithets, figurative simile, antithesis, pun, etc.[16, pp. 28-37]

Associative irony is more difficult and meaningful. It is realized in the megacontext (within the whole text). Associative irony is formed on the level of the text as a result of situational repetition (retrospection) combined with ironical allusion, grotesque, nonsense.

\section{ІРОНІЯ ТА ЗАСОБИ ЇЇ РЕАЛІЗАЦІЇ В АНГЛОМОВНОМУ ХУДОЖНЬОМУ ДИСКУРСІ (ПЕРЕКЛАДАЦЬКИЙ АСПЕКТ)}

Ю. В. Кац, канд. філол. наук, доцент;

Ю. О. Фадеєва, студентка

Сумський державний університет,

вул. Римського-Корсакова, 2, м. Суми, 40007, Украӥна

E-mail:juliakatz@ukr.net; yuliana.fadeeva@gmail.com

Поняття «іронія» існує в різних історико-філософських та лінгвістичних контекстах (починаючи від Сократа, Аристотеля $і$ до Постмодернізму). Кожна епоха привносила свої нюанси в його зміст, але в жодній системі категорій воно не могло претендувати на провідну роль. Тому перспективи його розвитку та вивчення залишаються відкритими.У сучасній лінгвістиці іронія розглядається як стилетворча риса тексту, яка може бути реалізована на різних мовних рівнях, від одного слова, висловлювання до цілісного тексту в обов'язковому контекстуальному оточенні. Велике значення контексту для декодування іронії зумовлює ї̈ інтелектуалізм $i$, як наслідок, зростання ї̈ ваги у сучасному мистецтві, розширення засобів $i$ механізмів ї̈ реалізаиії у художніх текстах. У изьому контексті значної ваги й актуальності набуває аналіз мовних засобів іронічності в англійському художньому дискурсі.

Ключові слова: іронія, стилістичний прийом, виразні засоби, невідповідність, ситуаційна іронія, асоціативна іронія, заперечення, лексичний рівень, синтаксичний рівень, перетворення. 


\section{ИРОНИЯ И СРЕДСТВА ЕЕ РЕАЛИЗАЦИИ В АНГЛОЯЗЫЧНОМ ХУДОЖЕСТВЕННОМ ДИСКУРСЕ (ПЕРЕВОДЧЕСКИЙ АСПЕКТ)}

Ю. В. Кащ, канд. филол. наук, дочент;

Ю. А. Фадеева, студентка

Сумский государственный университет,

ул. Римского-Корсакова, 2, г. Сумы, 40007, Украина

E-mail: juliakatz@ukr.net;yuliana.fadeeva@gmail.com

Понятие «ирония» существует в различных историко-философских и лингвистических контекстах (начиная от Сократа, Аристотеля и к Постмодернизму). Каждая эпоха привносила свои нюансы в его содержание, но ни в одной системе категорий оно не могло претендовать на ведущую роль. Поэтому перспективы его развития и изучения остаются открытыми.

В современной лингвистике ирония рассматривается как стилевая черта текста, которая может быть реализована на разных языковых уровнях, от одного слова, высказывания к иелостному тексту в обязательном контекстуальном окружении. Большое значение контекста для декодирования иронии предопределяет ее интеллектуализм и, как следствие, рост ее значимости в современном искусстве, расширение средств и механизмов ее реализачии в художественных текстах.

В этом контексте значительную значимость и актуальность приобретает анализ языковых средств ироничности в английском художественном дискурсе.

Ключевые слова: ирония, стилистический прием, выразительные средства, несоответствие, ситуационная ирония, ассочиативная ирония, отрицание, лексический уровень, синтаксический уровень, преобразования.

\section{REFERENCES}

1. Kalyta, O. M. (2004). Ironiya yak subkategoriya komichnogo [Irony as a subcategory of comic]. Naukovyi chasopis. Series 8 (Philology), 1, 67-71. Kyiv, Ukraine: NPU im. M. P. Drahomanova.

2. Kam"yanets', A. B. (2009). Vidtvorennya intertekstual'noi ironii v anhlo-ukrains'komu hudozhniomu perekladi [Reproduction of intertextual irony in the English-Ukrainian artistic translation]. Extended abstract of candidate's thesis. Kyiv, Ukraine.

3. Dzemidok, B. (1997). Pro komizm [About Comic]. Kyiv, Ukraine: Nauk. dumka.

4. Vorontsova, N. H. (2005). Komunikatyvno-kohnityvni osoblyvosti verbal'noi interakcii zi storonnim retsipiyentom (na materiali anhliys'koi movy) [Communicative-cognitive features of verbal interaction with a third-party recipient (on the material of the English language)]. Extended abstract of candidate's thesis. Lviv National University I. Franka, L'viv, Ukraine.

5. Lesyk, I. V. (2011). Efekt kontrastu yak vyjav paradoksal'nosti ironii [The effect of contrast as a paradoxical expression of irony]. Studia Germanica et Romanica: Foreign languages. World Literature. Teaching methods, 8(1), 41-52; Bibliogr, pp. 51-52.

6. Voloshchuk, I. I. (2006). Viznachennya ironiï v hudozhn'omu teksti ta diskursi [Definition of irony in artistic text and discourse]. Naukovi zapysky (pp. 42-44), Nizhyn. derzh. ped. un-t im. M. Hoholya, Nizhyn, Ukraine

7. Bekhta, I. A. (2010). Opovidnyi diskurs v anhlomovnii hudozhnii prozi: tipolohiya ta dynamyka movlennevyh form [Relevant Discourse in English Prose: Typology and Dynamics of Speech Forms]. Extended abstract of PhD thesis. Kyiv, Ukraine.

8. Prykhod'ko, H. I. (2001). Osoblyvosti realizatsii sarkazmu ta ironii v hudozhniomu teksti [Features of the realization of sarcasm and irony in the artistic text]. In D. S. Buraho (Ed.), Mova I Kul'tura, Iss. 3, Vol. 4: Mova I khudozhnia tvorchist (pp. 207-210). Kyiv, Ukraine.

9. Salihova, N. K. (1976). YAzykovaya priroda i funktsional'naya kharakteristika stilisticheskogo priyoma ironii [Linguistic nature and functional characteristic of stylistic reception of irony]. Extended abstract of candidate's thesis. Moscow, Russia.

10. Harris, Z. (1952). Discourse Analysis. Language, 28(17), 1-30.

11. Halliday, M. A. K. \&.Hasan, R. (1991). Language, context and text: aspects of language in a social-semiotic perspective. Oxford: Oxford University Press.

12. Brown, G. \& Yule, G. (1996). Discourse Analysis. Cambridge: Cambridge University Press.

13. Fairclough, N. (1992). Discourse and text: linguistic and intertextual analysis within discourse analysis. Discourse and Society, 3, 192-217.

14. Weisgerber, J. (1973). Satire and irony as means of communication. Comparative literature studies, 10(2), 157-172.

15. Ostman, J. \& Virtanen, T. (1995). Discourse analysis. Handbook of Pragmatics (pp. 239-253). Amsterdam, Philadelphia.

16. Pochodnia, S. I. (1989). YAzykovyie vidy i sredstva realizatsii ironii [Language Types and Means of Realizing Irony]. Kyiv: Naukova Dumka. 


\section{СПИСОК ВИКОРИСТАНИХ ДЖЕРЕЛ}

1. Калита О. М. Іронія як субкатегорія комічного / О. М. Калита // Науковий часопис. Збірник. Серія 8 Філологія. - К. : НПУ ім. М.П. Драгоманова, 2004. - Вип. 1. - С. 67-71.

2. Кам'янець А. Б. Відтворення інтертекстуальної іронії в англо-українському художньому перекладі : автореф. дис. ... канд. філол. наук: 10.02.16 / А. Б. Кам’янець.- К., 2009. - 19 с.

3. Дземідок Б. Про комізм / Богдан Дземідок. - К. : Наук. думка, 1997. - 284c.

4. Воронцова Н. Г. Комунікативно-когнітивні особливості вербальної інтеракції зі стороннім реципієнтом (на матеріалі англійської мови) : автореф. дис. ... канд. філол. наук / Н. Г. Воронцова; Львівський національний ун-т ім. І. Франка. - Л., 2005. - 21 с.

5. Лесик I. В. Ефект контрасту як вияв парадоксальності іронії / I. В. Лесик // Studia Germanica et Romanica: Іноземні мови. Зарубіжна література. Методика викладання. - 2011. - Т. 8, № 1. - C. 41-52. Бібліогр.: С. 51-52.

6. Волощук I. I. Визначення іронії в художньому тексті та дискурсі / I. І. Волощук // Наукові записки. Філологічні науки: зб. наук. ст. - Ніжин: Ніжин. держ. пед. ун-т ім. М. Гоголя, $2006 .-$ C. $42-44$.

7. Бехта I. А. Оповідний дискурс в англомовній художній прозі: типологія та динаміка мовленнєвих форм : автореф. дис. ... д-ра філол. наук : спец. 10.02.04 «Германські мови»/ Іван Антонович Бехта. Київ, 2010. - 37 с.

8. Приходько Г. І. Особливості реалізації сарказму та іронії в художньому тексті / Г. І. Приходько // Мова і культура. - К., 2001. - Вип.3, Т. 4: Мова і художня творчість. - С. 207-210. - (Філологія).

9. Салихова Н. К. Языковая природа и функциональная характеристика стилистического приема иронии: автореф. дис... канд. филол. наук. - М, 1976. - 24 с.

10. Harris Z. Discourse Analysis / Z. Harris // Language. - 1952. - Vol. 28, № 17. - pp. 1-30.

11. Halliday M. A. K. Language, context and text: aspects of language in a social-semiotic perspective / M. A. K. Halliday, R.Hasan. - Oxford : Oxford University Press, 1991. - 264 p.

12. Brown G. Discourse Analysis / G. Brown, G. Yule. - Cambridge: Cambridge University Press, 1996. - 288 p.

13. Fairclough N. Discourse and text: linguistic and intertextual analysis within discourse analysis / N. Fairclough // Discourse and Society. - 1992. - № 3. - P. 192-217.

14. Weisgerber J. Satire and irony as means of communication / J. Weisgerber // Comparative literature studies. 1973. - Vol.10, № 2. - P. 157-172.

15. Ostman J. Discourse analysis / J. Ostman, T. Virtanen // Handbook of Pragmatics.- Amsterdam, Philadelphia, 1995. - Р. 239-253.

16. Походня С. И. Языковые виды и средства реализации иронии / С. И. Походня. - Киев : Наукова думка, 1989. $-128 \mathrm{c}$

Received: 31 January 2018 